\title{
Metagenomic Profiles of Antibiotic Resistance Genes in Activated Sludge, Dewatered Sludge and Bioaerosols
}

\author{
Il Han ${ }^{1}$ (D) and Keunje Yoo ${ }^{2, *(\mathbb{D})}$ \\ 1 Department of Civil and Environmental Engineering, Princeton University, Princeton, NJ 08544, USA; \\ hil8286@gmail.com \\ 2 Department of Environmental Engineering, Korea Maritime and Ocean University, Busan 49112, Korea \\ * Correspondence: kjyoo@kmou.ac.kr; Tel.: +82-514104416
}

Received: 25 March 2020; Accepted: 22 May 2020; Published: 26 May 2020

\begin{abstract}
Wastewater treatment plants (WWTPs) have been considered hotspots for the development and dissemination of antibiotic resistance in the environment. Although researchers have reported a significant increase in bioaerosols in WWTPs, the associated bacterial taxa, antibiotic resistance genes (ARGs), and mobile genetic elements (MGEs) remain relatively unknown. In this study, we have investigated the abundance and occurrences of ARGs and MGEs, as well as the bacterial community compositions in activated sludge (AS), dewatered sludge (DS) and bioaerosols (BA) in a WWTP. In total, 153 ARG subtypes belonging to 19 ARG types were identified by the broad scanning of metagenomic profiles obtained using Illumina HiSeq. The results indicated that the total occurrences and abundances of ARGs in AS and DS samples were significantly higher than those in BA samples $(p<0.05)$. However, some specific ARG types related to sulfonamide, tetracycline, macrolide resistance were present in relatively high abundance in BA samples. Similar to many other full-scale WWTPs, the Proteobacteria (58\%) and Bacteroidetes (18\%) phyla were dominant in the AS and DS samples, while the Firmicutes (25\%) and Actinobacteria (20\%) phyla were the most dominant in the BA samples. Although the abundance of genes related to plasmids and integrons in bioaerosols were two to five times less than those in AS and DS samples, different types of MGEs were observed in BA samples. These results suggest that comprehensive analyses of resistomes in BA are required to better understand the emergence of both ARGs and MGEs in the wastewater treatment process due to the significant increase of scientific attention toward bioaerosols effects.
\end{abstract}

Keywords: antibiotic resistome; wastewater residual; wastewater treatment plant; bioaerosols; metagenomics

\section{Introduction}

The intensive use of antibiotics in the clinical, industrial, and agricultural sectors has encouraged the selection of antibiotic-resistant bacteria (ARB) and genes (ARGs) since the first deployment of antibiotics in the 1930s [1]. Currently, infections resistant to antimicrobial therapy are costing hundreds of thousands of lives worldwide, and the death toll is projected to further increase each year [2]. Factors influencing the environmental resistome have attracted significant interest from scientists [3,4], and it is widely recognized that wastewater treatment plants (WWTPs) are among the primary anthropogenic sources of ARB and ARGs in the natural environment [5-8]. Additionally, mobile genetic elements (MGEs) are abundant in WWTPs [9] and have been suggested to aid in the horizontal gene transfer (HGT) of ARGs within the treatment process [3,10], as well as in the receiving water [11,12]. Therefore, common byproducts of wastewater treatment processes, such as activated sludge and dewatered 
sludge (hereafter referred to as WWTP byproducts), can disseminate resistomes to other environments without proper management.

The occurrence and abundance of ARB and ARGs in activated sludge $[7,9,13]$, as well as their removal by different wastewater treatment processes [3,14-16], are undergoing continuous research. Many studies have extended their scope to the water [17], soil, and sediment $[15,18]$ that receives the WWTP byproducts. However, the antibiotic resistance of biological aerosols (bioaerosols) generated by wastewater treatment processes has seldom been investigated. Bioaerosols have shown connections with a variety of contagious infections in people [19], and ARGs have also been discovered in urban air $[20,21]$. A significant increase in bioaerosols was observed on the day after the start of a new WWTP, indicating a link between the bioaerosol properties and plant operation [22]. More alarmingly, bioaerosols from WWTPs were found $10 \mathrm{~km}$ downwind of the plant boundaries [23]. Previous studies showed a possible connection between specific bacterial species and ARGs of WWTP samples [24,25]. Nevertheless, to the best of our knowledge, no research has comprehensively analyzed how the bacterial community and the ARG relative content change as activated sludge is processed into dewatered sludge and aerosolized into bioaerosols. In addition, few studies have simultaneously investigated the profiles of MGEs, even though they are important factors for the HGT that affects the acquisition and transfer of ARGs in the bacterial community $[9,15]$.

The objective of this study is to preliminarily investigate the abundance and diversity of ARGs, bacterial taxa, and MGEs in WWTP byproducts and bioaerosols using a shotgun metagenomic analysis.

\section{Materials and Methods}

\subsection{Study Area and Sampling}

In total, six samples (2 activated sludges: AS, 2 dewatered sludges: DS, and 2 bioaerosols: BA) were collected from the Jungnang municipal WWTP $\left(37^{\circ} 33^{\prime} 28.2^{\prime \prime} \mathrm{N}, 127^{\circ} 03^{\prime} 54.9^{\prime \prime} \mathrm{E}\right)$ during the winter season (January and November) in 2015 in Seoul, South Korea. The WWTP has a treatment capacity of $1.6 \times 10^{6} \mathrm{~m}^{3} /$ day and serves approximately 4.1 million inhabitants. The WWTP process consists of screens, a grit chamber and a modified Ludzack-Ettinger (MLE) system, which includes an anoxic tank and an aerobic tank, followed by a secondary clarifier. Part of the activated sludge is returned to the anoxic tank from the aerobic tank. The influent biochemical oxygen demand (BOD), total nitrogen (TN) and total phosphorous (TP) were approximately $115.5-124.0 \mathrm{mg} / \mathrm{L}, 29-33 \mathrm{mg} / \mathrm{L}$ and $3.44-3.87 \mathrm{mg} / \mathrm{L}$, respectively, and their average removal efficiencies were $94.3 \%, 58.03 \%$ and $65.4 \%$, respectively. The influent sludge compositions were 113.8-115.7 total suspended solids (TSS) $\mathrm{mg} / \mathrm{L}$, 110.1-112.4 BOD mg/L, and 29.7-30.2 TN mg/L, while the effluent TSS, BOD and TN were 4.1-4.4 mg/L, $6.9-8.4 \mathrm{mg} / \mathrm{L}$, and $9.7-12.8 \mathrm{mg} / \mathrm{L}$, respectively.

Activated sludges $(500 \mathrm{~mL})$ were collected from an aeration tank during the MLE process. Dewatered sludges were also collected from the belt-press inside the dewatering system unit on the same day. Bioaerosols samples were collected beside the belt-press on sterilized $0.2 \mu \mathrm{m}$ track-etched polycarbonate filters (Whatman, GE, Freiburg, Germany) using two high-volume air samplers (Model TE 5200, Tisch Environmental, Inc., Cleves, OH, USA) at a flow rate of $1.5 \mathrm{~m}^{3} \mathrm{~min}^{-1}$ for $24 \mathrm{~h}$. The polycarbonate filters were autoclaved prior to sampling, and the filter holders were washed with $70 \%$ ethanol at the sampling time to avoid potential contamination [26]. The temperature and relative humidity inside the dewatering facility were $22{ }^{\circ} \mathrm{C}$ and $19 \%$, respectively. The collected samples were immediately transferred to the laboratory in an ice box and stored at $-80^{\circ} \mathrm{C}$ for molecular analysis.

\subsection{DNA Extraction and High-Throughput Sequencing}

The FastDNA Spin Kit for Soil (MP Biomedicals, Santa Ana, CA, USA) was used to extract genomic DNA from six samples, according to the manufacturer's protocol. For the sludge and dewatered sludge samples, DNA was extracted from the cell pellet formed after centrifuging $1.5 \mathrm{~mL}$ of each sample at $14,000 \times g$ for $2 \mathrm{~min}$. For the bioaerosol samples, gDNA was extracted from the filter pieces by a method 
described in previous studies [26,27]. The quality of the extracted DNA was checked using a Qubit Fluorometer (Thermo, Wilmington, DE, USA) for the subsequent shotgun metagenome sequencing. The metagenome sequencing was performed by Macrogen (Seoul, South Korea) using the TruSeq DNA PCR-Free Kit (Invitrogen, Inc., Madison, WI, USA) according to the library protocol. Each sample was barcoded and analyzed using a $2 \times 101$ bp paired-end protocol with an Illumina HiSeq 2000 platform.

\subsection{Bioinformatics Analysis}

Trimmomatic (version 0.33) was used to trim adaptors and nucleotide stretches with low quality scores (default setting) from the Illumina results [28], which were then used as inputs for the downstream analysis. The diversity and abundance of ARGs and ARGs-OAP (Online Analysis Pipeline) were determined using the online tool (http://smile.hku.hk/SARGs), following a previously published protocol [29]. For the ARG abundances, the copies of ARGs per copy of 16S rRNA in the metagenomic data were used [27].

To characterize the MGEs in the tested samples, sequences found in the AS, DS, and BA were aligned against the integron and plasmid database using Local BLASTn. An integron database was constructed using the nucleotide sequences of all integrases available in the INTEGRALL database (http://integrall.bio.ua.pt/). Similarly, a plasmid database was developed on the basis of the plasmid sequences of the NCBI RefSeq database (http://www.ncbi.nlm.nih.gov/refseq). A read was annotated as an integron if the nucleotide sequence identity of the best BLASTn was greater than $90 \%$ with an alignment length of at least $50 \mathrm{bp}$. The plasmid-like tags in all data sets were determined by alignments with a nucleotide sequence identity above $95 \%$ over a length of at least $90 \mathrm{bp}[30,31]$.

The microbial communities of the tested samples were analyzed using the default setting of MetaPhlAn2 [32]. All statistical analyses (t-test and correlation analysis) were conducted using the "vegan" package in R software. The metagenomes generated in this study are uploaded at MG-RAST (sample ID: mgm4785061.3, mgm4791578.3, and mgm4791579.3).

\section{Results and Discussion}

\subsection{Prevalence of $A R G$ s in $A S, D S$, and $B A$}

WWTPs are regarded as hotspots for ARGs and ARB [5,9]. In this study, a metagenomic analysis of the activated sludge (AS), dewatered sludge (DS) and bioaerosols (BA) revealed 153 different ARG subtypes belonging to 19 ARG types. The AS samples contained 138 ARG subtypes representing $0.093 \pm 0.006 \%$ of the total reads (Figure 1). The average values of ARGs ranged from $5.80 \times 10^{-5}-1.20 \times$ $10^{-1}$ copies per $16 \mathrm{~S}$ rRNA gene in the AS samples. This result was comparable to that obtained for DS samples, which contained 144 ARG subtypes representing $0.092 \pm 0.010 \%$ of the total reads. The average values of ARGs ranged from $4.62 \times 10^{-6}-4.48 \times 10^{-1}$ copies per $16 \mathrm{~S}$ rRNA gene in the DS samples. In contrast, the BA samples contained only 98 ARG subtypes representing $0.025 \pm 0.004 \%$ of the total reads. The average values of ARGs ranged from $7.88 \times 10^{-7}-3.16 \times 10^{-3}$ copies per $16 \mathrm{~S}$ rRNA gene in the BA samples. Among them, sulfonamide (sulI, sulII)-, MLS (ermB, erm $\mathrm{G}$, ermF)- and tetracycline $($ tet $\mathrm{A}$, tet $\mathrm{G}$, tet $\mathrm{Q}$, tet $\mathrm{W})$-resistance genes accounted for approximately $71 \%$ of the total identified $\mathrm{ARGs}$ across the three different sample types (Figure 2). Although the residual pharmaceuticals found in the influent can vary based on the purpose and service area of a WWTP [33], the influent pharmaceutical concentration at large-scale municipal WWTPs in South Korea, such as the Jungnang WWTP, correlated well with the antibiotic usage [34]. Given that sulfonamide, MLS and tetracycline are common antibiotics used in both healthcare and agriculture [35,36], continuous exposure to the residues from these antibiotics could have resulted in the high abundances of these ARGs. Similarly, genes conferring resistance to sulfonamides and MLS are frequently detected in WWTPs around the world, along with those providing resistance to tetracyclines and beta-lactams $[37,38]$. There are also reports of considerable increases (over two orders of magnitude) in sul, erm, and tet during the treatment processes $[9,13,37]$. Especially, resistance genes of $\beta$-Lactam were relatively predominant in the AS 
samples in this study $(p<0.05)$. OXAs (Oxacillinases) genes were commonly detected in gram-negative bacteria [39]. Because OXA enzymes are usually associated with MGEs, such as integrons, insertion sequences and transposons, they potentially can be transferred between bacterial communities via HGT [40]. In addition, they were usually co-selected with other resistance determinants, such as aminoglycosides, sulfonamide, fluoroquinolones, and tetracycline. It suggests that OXA genes may be a major driver of spreading of antibiotic resistomes in the AS process $[39,40]$.

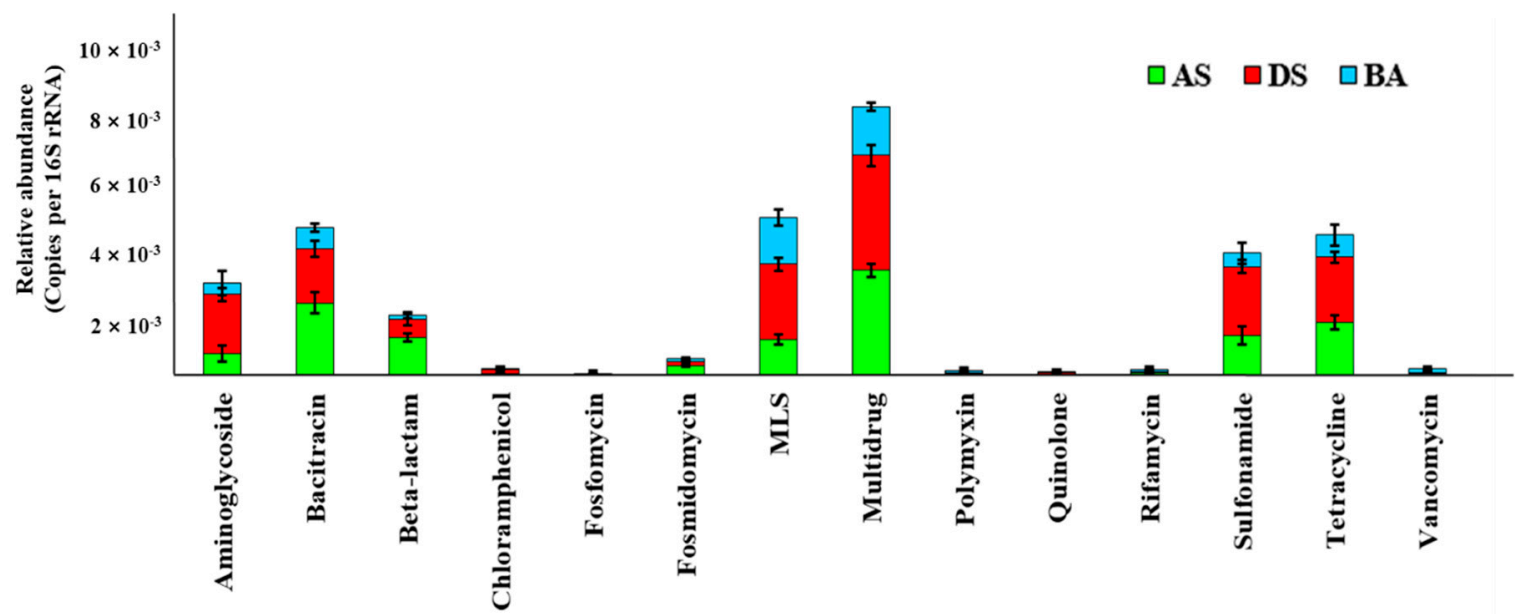

Figure 1. The relative abundances of the antibiotic resistance genes (ARG) types in AS (activated sludge), DS (dewatered sludge), and BA (bioaerosols). MLS indicates macrolide-lincosamide-streptogramin. The error bars represent one standard deviation between two samples (January and November).

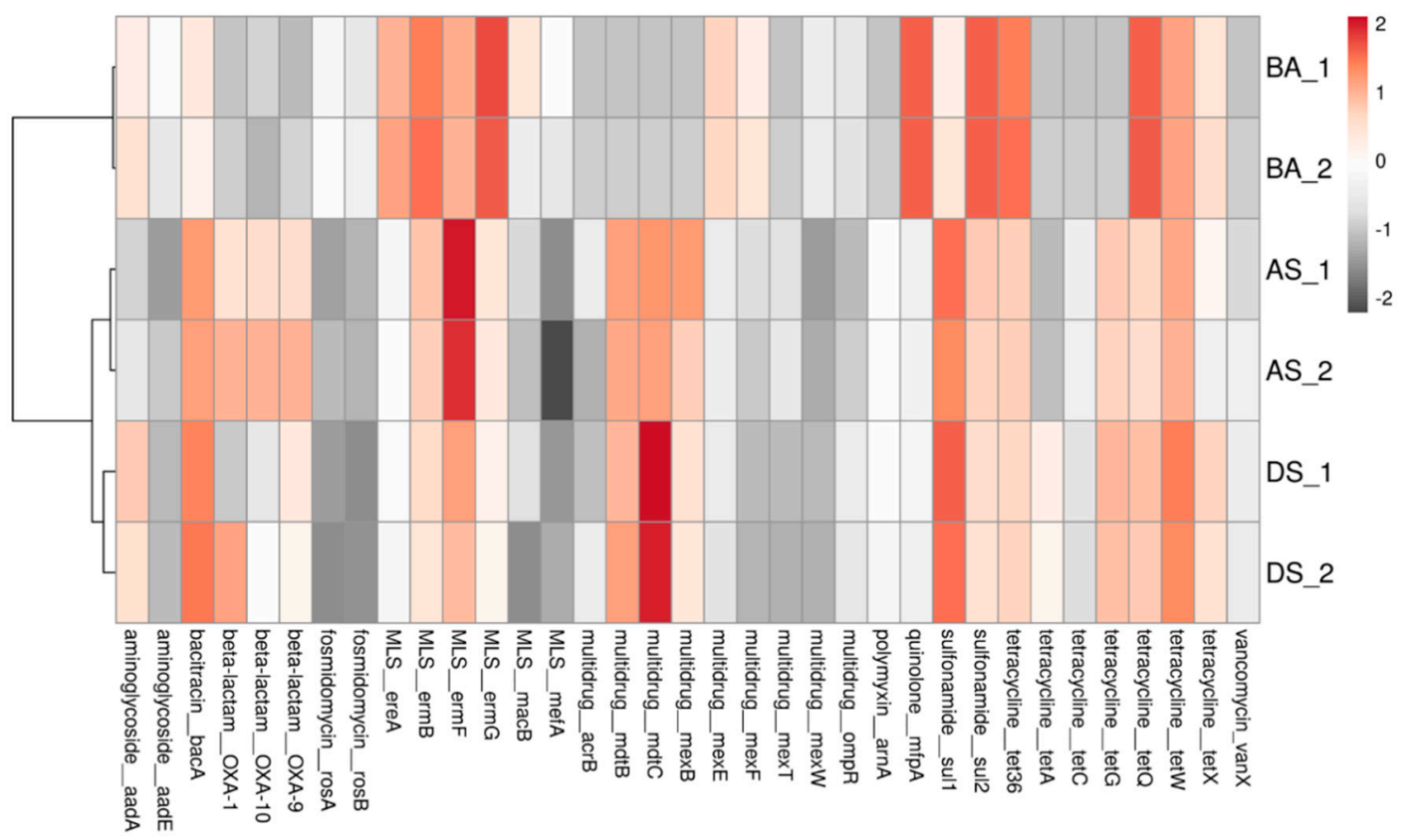

Figure 2. Broad-spectrum profiles of the ARG subtypes in AS (activated sludge), DS (dewatered sludge), and BA (bioaerosols). The abundances of the top 35 ARG subtypes (ARG per copy of 16S rRNA gene copies) are illustrated in the heat map using the normalized z-score for all samples. AS1, DS1, and BA1 indicate January samples in 2015, and AS2, DS2, and BA2 indicate November samples in 2015.

In a previous study, the total number of ARGs in DS was at least an order of magnitude higher than that in AS, with no major change in the relative compositions of ARG types [13]. In this study, the total number of ARGs found in DS was also higher than that in AS. However, the relative compositions 
of ARG types were notably different before and after the dewatering process, according to a t-test $(p<0.05)$ (Figure 2). In the AS samples, sulI, sulII and ermF constituted $24 \%, 7 \%$ and $28 \%$ of the total ARG composition, respectively. However, in the DS samples, their compositions changed to $29 \%, 4 \%$ and $18 \%$, respectively. Sulfonamides, with their high solubility and chemical stability, can persist in the environment for a long period of time [41], resulting in the high abundance of sulI and sulII in the WWTPs. Therefore, sulfonamide resistance is frequently detected in effluent $[3,4,17]$, dewatered sludges [42], and surface water $[6,43,44]$, indicating a general resilience to the wastewater treatment process. In addition, many sulI genes are suscpetible to HGT because they are carried by the integrase gene of class 1 integrons (intI1), which are MGEs [45]. Ma et al. [46] reported a rebound of sulI after the aerobic digestion of sludge that was pretreated by thermal hydrolysis. This result not only suggests the persistence of sulI in a wide variety of environments, but it also indicates the possibility of HGT in the bacterial community, which is greatly aided by MGEs like intI1 [37,38].

A lower number of ARG types and subtypes were found in the BA, comparing with AS and DS (Figure 2). Among them, erm, sul, and tet were dominant, constituting approximately $62 \%$ of the total ARG composition. While sull was significantly decreased in the bioaerosols compared with both the AS and DS samples $(p<0.05)$, the relative abundance $(16 \%)$ was still high. Although ARGs in the atmosphere have recently attracted scientific attention [21,23,47], the low number of metagenomic investigations in this field limits direct comparisons of the results obtained from this study. Nevertheless, the major profile of ARGs in the bioaerosols (erm, sul, and tet gene) was similar to those in sludge thickening basins [23], biological reaction basins [23], mass livestock-feeding operation facilities [48,49] and urban air [50]. These results indicate that the profiles of ARGs in BA from WWTP are commonly detected in other types of air samples, but the reason behind the dominance of erm, sul, and tet is still unclear. Zhou et al. [21] reported that rapid changes in physicochemical conditions may occur during and after aerosolization. These changes might either amplify or attenuate ARB [6,9,51,52], developing different ARG abundances and diversity levels in BA. ARB and ARGs in bioaerosols are particularly important because they can be easily transported by wind, spreading resistance to distant areas [49]. However, there is a major concern about the reliability of the results, because our sample size is small for interpreting the different occurrences and abundances of ARGs among the AS, DS, and BA samples. However, sometimes small samples detect more rare members and may help in the preliminary investigation of study needs by directing scientific attention toward rapidly understanding the overall trends and characteristics of the microbial communities [53]. Some previous studies [9,54] have been carried out to investigate the structures, functions, and resistomes of microbial communities from WWTPs using small sample sizes. Therefore, further investigation is quite needed to understand the cause of the enrichment of ARG abundance in the bioaerosols.

\subsection{Phylogenetic Characterization of the Bacterial Community}

The taxonomic profiles at the phylum and genus levels were investigated to interpret the changes in the bacterial community structure as activated sludge is pressed into dewatered sludge and then aerosolized (Figure 3). Similar to many other full-scale WWTPs, Proteobacteria (57.82\%-59.58\%) and Bacteroidetes $(20.32 \%-22.24 \%)$ were dominant in the AS samples [55,56]. These phyla were dominant even after the dewatering process, but their genus-level profiles were notably different (Figure 3). The AS samples were dominated by nitrifiers (Nitrosomonas, 10\%-11\%; Nitrospira, 8\%-9\%), denitrifiers (Dechloromonas, 18-20\%), and Escherichia (8\%-11\%), whereas Pseudomonas (20\%-22\%), Mycobacterium (17\%-19\%), and Arthrobacter (13\%-14\%) were more dominant in the DS samples. The physiochemical changes affecting activated sludge during its conversion to dewatered sludge are mechanical actions that rapidly squeeze out liquid and some biomasses [23]. The force exerted on the sludge in this process causes an unnatural shift in the environmental parameters (temperature, substrate, nutrients, etc.), which can have substantial effects on bacterial community structures and ARGs [7,37]. 
(a)
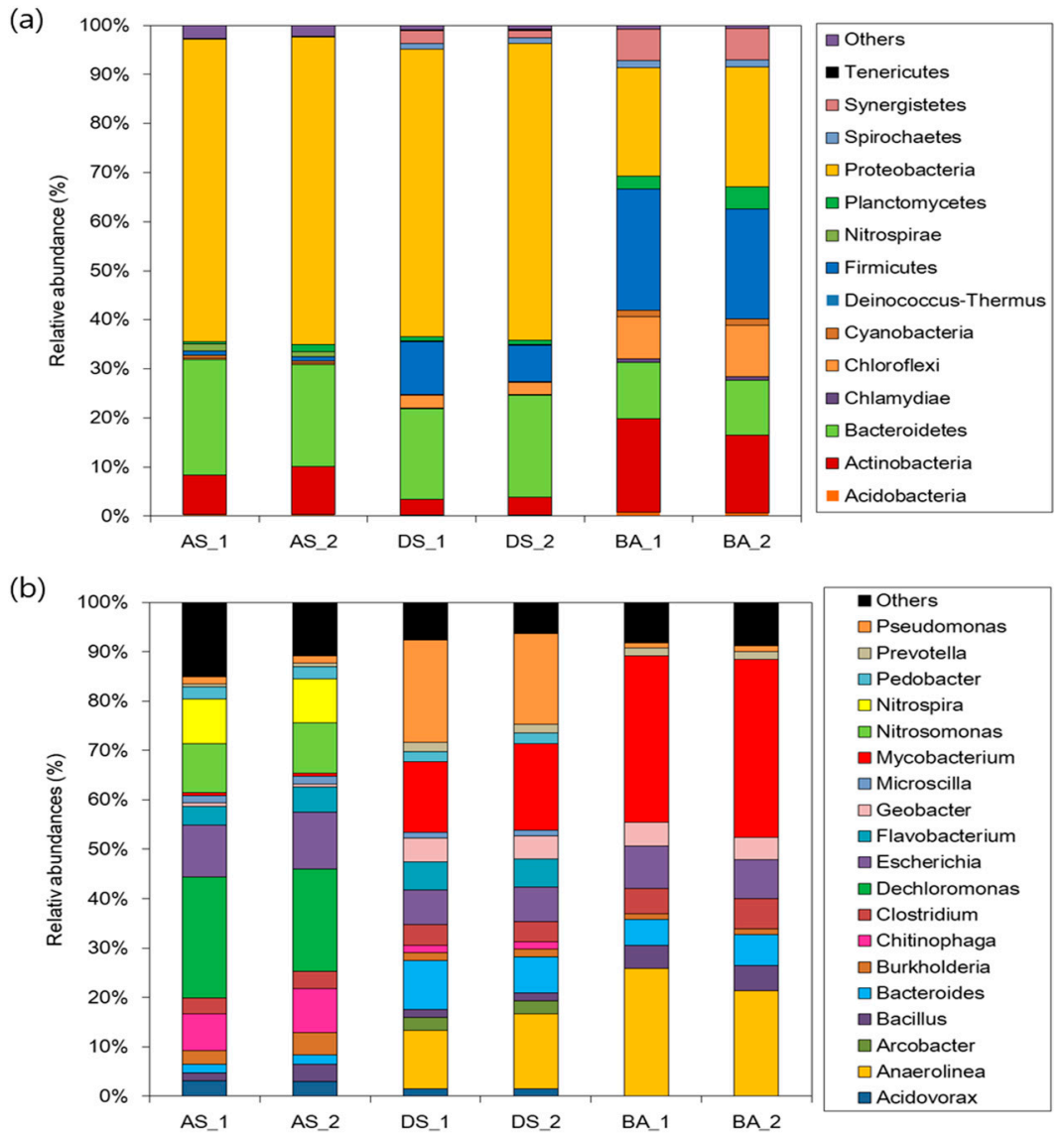

Figure 3. The relative abundances of the major detected phyla (a) and genera (b) in the AS, DS, and BA samples. AS1, DS1, and BA1 indicate January samples in 2015, and AS2, DS2, and BA2 indicate November samples in 2015.

According to a previous study, as much as $85.27 \%$ of the bioaerosols in the dewatering facility are emitted from sludge during dewatering [57]. However, the bacterial community structures of the bioaerosols were different from those in the WWTP byproducts, which are the most likely source. In the bioaerosols, the phyla Firmicutes $(25.40 \%-27.12 \%)$ and Actinobacteria $(20.38 \%-22.06 \%)$ were the most dominant, constituting a significantly higher proportion $(p<0.05)$ of the bacterial community structure than in the WWTP byproducts. Consequently, the bacterial community structure at the genus level was also different from that of the WWTP byproducts. Mycobacterium (25\%-28\%) was the most dominant genus found in the bioaerosols. This was consistent with a previous study, which revealed relatively high proportions of Mycobacterium in the air of sludge dewatering facilities [57]. Such a difference could also result from the rapid change in physicochemical conditions due to the aerosolization of liquids and semisolids, such as the rapid changes to which active sludge was exposed during the dewatering process. However, the different incidences of bacterial communities were not clearly demonstrated in this study due to the sample sizes. In addition, relatively fewer studies have been carried out to understand the microbial communities of bioaerosols from WWTPs. Therefore, more studies are absolutely required to better understand the emergence of both bacterial communities and ARGs in wastewater treatment processes in full-scale WWTPs.

\subsection{Prevalence of Mobile Genetic Elements (MGEs)}

MGEs, such as plasmids and integrons, can facilitate the HGT of ARGs linked to them. As one major player in the dissemination of antibiotic resistance, intI1 is ubiquitous in soil, freshwater, and biofilms and is present in $1 \%-5 \%$ of bacterial cells [58]. In the AS, approximately $0.284 \pm 0.016 \%$ and $0.023 \pm 0.020 \%$ of the identified genes were related to plasmids and integrons, respectively (Figure 4 ). 
The genes related to plasmids decreased to $0.22 \pm 0.010 \%$, whereas those related to integrons increased to $0.030 \pm 0.022 \%$ after the DS. In comparison, the abundances of genes related to plasmids and integrons in the BA were two to five times less than those in the AS and DS, with values of $0.112 \pm 0.007 \%$ and $0.008 \pm 0.002 \%$, respectively. The distribution of MGE abundance and MGE diversity were consistent with those of the ARGs of the tested samples.

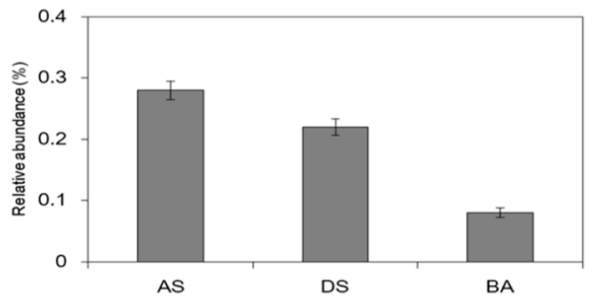

(a)

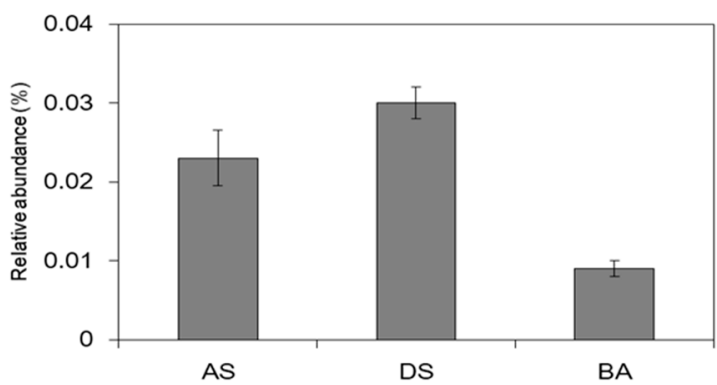

(b)

Figure 4. Distribution of mobile genetic elements, including plasmids (a) and integrons (b), across the three different samples (AS (activated sludge), DS (dewatered sludge), and BA (bioaerosols)). Relative abundances of plasmid- and integron-like reads per total metagenomic sequencing read. The error bars represent one standard deviation.

Many plasmids and intI1 were found in the WWTP byproducts and bioaerosols (Tables S1 and S2). The ARG diversity and abundance showed strong correlations with those of the plasmids, with $\mathrm{R}^{2}$ values of 0.66 to 0.84 , respectively (Table S3). However, among the major plasmids, only one was present in more than one sample (pMaq22A_1p in activated sludge and dewatered sludge). Although different ARG profiles were detected from each type of sample, the correlations between ARGs and plasmids may potentially aid in the persistence of ARGs under different environmental conditions. Plasmids conferring antibiotic resistance are known to be stable in the environment, even without antibiotic selection pressures $[13,15,17,58,59]$. Especially, the presence of self-transmissible plasmids, such as the atrazine catabolic plasmid pADP-1 [60], and putative conjugative plasmids, such as pAR060302 [61] and pPS1 [62], may reinforce the hypothesis of frequent plasmid transfer events between ARGs and bacterial communities during treatment processes, or these plasmids may spread through the acceleration of the ARGs mobility. Thus, the high abundance of plasmids potentially leads to the enrichment of multiple ARGs in wastewater treatment processes. Integrons are suggested to contribute to the exchange and incorporation of ARGs, resulting in the proliferation of bacterial antibiotic resistance in WWTPs $[10,58,63,64]$. Therefore, plasmid- and intI1 gene-related antibiotic resistance in WWTP byproducts and bioaerosols may increase environmental and public health risks if they are released without proper treatment.

Although antibiotic resistance could spread among bacteria through HGT, the transfer rate may not be high enough to impose the change observed in the number of ARGs, unless the tested samples have been resting in the WWTP for a long period of time. The short transition and incubation time $(<24 \mathrm{~h})$ are unlikely to have caused a noticeable change in the resistome. Resistance found in the bacteria indigenous to the wastewater treatment environment potentially implies the occurrence of HGT between pathogens and environmental bacteria within the components of the WWTP $[9,12,63]$. To date, information regarding nonpathogenic environmental species, which can be important carriers of ARGs, is scarce. The potential risks of these nonpathogenic environmental species contributing to the spread of antibiotic resistance need to be assessed in future studies. A bacterial community shift via HGT was reported to be the major driver shaping the resistome of drinking water systems [64] and composting sewage sludge [65]. Therefore, it is possible that the dominant ARB listed above are counter-selected by the rapid transformation process from liquid to semisolid and then to aerosols based on their persistence under specific environmental conditions $[16,63,65]$. 


\section{Conclusions}

This study showed diverse ARGs and MGEs in WWTP byproducts and their connection to bioaerosols through metagenomic profiling. Although a solid conclusion cannot be made based on the limited number of samples investigated in this study, bioaerosols from the WWTP dewatering facility had different microbial community structures (Fermicutes and Acinetobacter were dominant) and ARGs (erm, sul, and tet genes were dominant) compared to WWTP byproducts. This indicates rapid changes in the biotic properties of activated sludge and dewatered sludge as they are aerosolized during the dewatering process. The results from this study provide new insight into the occurrence and abundance of ARGs in three different potential pollutants generated in the WWTP process, but future studies must evaluate whether the trends described in this study hold when larger sample sizes are used because of the limited robustness of our findings. In addition, further high-throughput sequencing of the metagenome and meta-transcriptome in future studies can be efficiently used as a tool to understand and build a strategy against the contamination of ARGs in WWTP processes.

Supplementary Materials: The following are available online at http://www.mdpi.com/2073-4441/12/6/1516/s1, Table S1: Relative abundances of plasmids and their corresponding bacterial hosts as determined by matching metagenomic sequence reads against the NCBI plasmid genome database, Table S2: Relative abundances of the integron integrase genes and their corresponding bacterial hosts as determined by matching metagenomic sequence reads against the INTEGRALL database, Table S3: The correlation between antibiotic resistance genes (ARGs) and mobile genetic elements (MGEs).

Author Contributions: K.Y. and I.H. performed the sampling and experiments; K.Y. and I.H. analyzed the data and wrote the paper. All authors have read and agreed to the published version of the manuscript.

Funding: This research was supported by Basic Science Research Program through the National Research Foundation of Korea (NRF) funded by the Ministry of Education; This work was also supported by the Korea Maritime and Ocean University Research Fund.

Conflicts of Interest: The authors declare no conflict of interest.

\section{References}

1. Walsh, C. Antibiotics: Actions, Origins, Resistance; ASM Press: Washington, DC, USA, 2003.

2. O'Neill, J. 2016 Tackling Drug-Resistant Infections Globally: Final Report and Recommendations. Available online: https://amr-review.org/sites/default/files/160525_Final\%20paper_with\%20cover.pdf (accessed on 10 December 2018).

3. Rizzo, L.; Manaia, C.; Merlin, C.; Schwartz, T.; Dagot, C.; Ploy, M.C.; Michael, I.; Fatta-Kassinos, D. Urban wastewater treatment plants as hotspots for antibiotic resistant bacteria and genes spread into the environment: A review. Sci. Total Environ. 2013, 447, 345-360. [CrossRef] [PubMed]

4. Bouki, C.; Venieri, D.; Diamadopoulos, E. Detection and fate of antibiotic resistant bacteria in wastewater treatment plants: A review. Ecotoxicol. Environ. Saf. 2013, 91, 1-9. [CrossRef] [PubMed]

5. Pruden, A.; Larsson, D.J.; Amézquita, A.; Collignon, P.; Brandt, K.K.; Graham, D.W.; Lazorchak, J.M.; Suzuki, S.; Silley, P.; Snape, J.R.; et al. Management options for reducing the release of antibiotics and antibiotic resistance genes to the environment. Environ. Heal. Persp. 2013, 121, 878-885. [CrossRef] [PubMed]

6. Li, B.; Yang, Y.; Ma, L.; Ju, F.; Guo, F.; Tiedje, J.M.; Zhang, T. Metagenomic and network analysis reveal wide distribution and co-occurrence of environmental antibiotic resistance genes. ISME J. 2015, 9, 2490-2502. [CrossRef] [PubMed]

7. Yoo, K.; Yoo, H.; Lee, J.; Choi, E.; Park, J. Exploring the antibiotic resistome in activated sludge and anaerobic digestion sludge in an urban wastewater treatment plant via metagenomic analysis. J. Microbiol. 2020, 58, 123-130. [CrossRef]

8. Quach-Cu, J.; Herrera-Lynch, B.; Marciniak, C.; Adams, S.; Simmerman, A.; Reinke, R.A. The Effect of Primary, Secondary, and Tertiary Wastewater Treatment Processes on Antibiotic Resistance Gene (ARG) Concentrations in Solid and Dissolved Wastewater Fractions. Water 2018, 10, 37. [CrossRef]

9. Guo, J.; Li, J.; Chen, H.; Bond, P.L.; Yuan, Z. Metagenomic analysis reveals wastewater treatment plants as hotspots of antibiotic resistance genes and mobile genetic elements. Water Res. 2017, 123, 468-478. [CrossRef] [PubMed] 
10. Martinez, J.L. Environmental pollution by antibiotics and by antibiotic resistance determinants. Environ. Pollut. 2009, 157, 2893-2902. [CrossRef]

11. Li, J.; Cheng, W.; Xu, L.; Jiao, Y.; Baig, S.A.; Chen, H. Occurrence and removal of antibiotics and the corresponding resistance genes in wastewater treatment plants: Effluents' influence to downstream water environment. Environ. Sci. Pollut. R. 2015, 23, 6826-6835. [CrossRef]

12. Karkman, A.; Do, T.T.; Walsh, F.; Virta, M.P. Antibiotic-resistance genes in wastewater. Trends Microbiol. 2018, 26, 220-228. [CrossRef]

13. Mao, D.; Yu, S.; Rysz, M.; Lou, Y.; Yang, F.; Li, F.; Hou, J.; Mu, Q.; Alvarez, P.J.J. Prevalence and proliferation of antibiotic resistance genes in two municipal wastewater treatment plants. Water Res. 2015, 85, 458-466. [CrossRef] [PubMed]

14. Diehl, D.L.; LaPara, T.M. Effect of temperature on the fate of genes encoding tetracycline resistance and the integrase of class 1 integrons within anaerobic and aerobic digesters treating municipal wastewater solids. Environ. Sci. Technol. 2010, 44, 9128-9133. [CrossRef]

15. Chen, B.; Yang, Y.; Liang, X.; Yu, K.; Zhang, T.; Li, X. Metagenomic profiles of antibiotic resistance genes (ARGs) between human impacted estuary and deep ocean sediments. Environ. Sci. Technol. 2013, 47, 12753-12760. [CrossRef] [PubMed]

16. Burch, T.R.; Sadowsky, M.J.; LaPara, T.M. Fate of Antibiotic Resistance Genes and Class 1 Integrons in Soil Microcosms Following the Application of Treated Residual Municipal Wastewater Solids. Environ. Sci. Technol. 2014, 46, 5620-5627. [CrossRef] [PubMed]

17. Xu, J.; Xu, Y.; Wang, H.; Guo, C.; Qiu, H.; He, Y.; Zhang, Y.; Li, X.; Meng, W. Occurrence of antibiotics and antibiotic resistance genes in a sewage treatment plant and its effluent-receiving river. Chemosphere 2015, 119, 1379-1385. [CrossRef]

18. Ross, J.; Topp, E. Abundance of antibiotic resistance genes in bacteriophage following soil fertilization with dairy manure or municipal biosolids, and evidence for potential transduction. Appl. Environ. Microbiol. 2015, 81, 7905-7913. [CrossRef]

19. Yoo, K.; Lee, T.K.; Choi, E.J.; Yang, J.; Shukla, S.K.; Hwang, S.I.; Park, J. Molecular approaches for the detection and monitoring of microbial communities in bioaerosols: A review. J. Environ. Sci. 2017, 51, 234-247. [CrossRef]

20. Yang, Y.; Zhou, R.; Chen, B.; Zhang, T.; Hu, L.; Zou, S. Characterization of airborne antibiotic resistance genes from typical bioaerosol emission sources in the urban environment using metagenomic approach. Chemosphere 2018, 213, 463-471. [CrossRef]

21. Zhou, H.; Wang, X.; Li, Z.; Kuang, Y.; Mao, D.; Lou, Y. Occurrence and Distribution of Urban Dust-Associated Bacterial Antibiotic Resistance in Northern China. Environ. Sci. Technol. Lett. 2018, 5, 50-55. [CrossRef]

22. Brandi, G.; Sisti, M.; Amagliani, G. Evaluation of the environmental impact of microbial aerosols generated by wastewater treatment plants utilizing different aeration systems. J. Appl. Microbiol. 2000, 88, 845-852. [CrossRef]

23. Li, J.; Zhou, L.; Zhang, X.; Xu, C.; Dong, L.; Yao, M. Bioaerosol emissions and detection of airborne antibiotic resistance genes from a wastewater treatment plant. Atmos. Environ. 2016, 124, 404-412. [CrossRef]

24. Makowska, N.; Koczura, R.; Mokracka, J. Class1 integrase, sulfonamide and tetracycline resistance genes in wastewater treatment plant and surface water. Chemosphere 2016, 144, 1665-1673. [CrossRef] [PubMed]

25. Lee, J.; Jeon, J.H.; Shin, J.; Jang, H.M.; Kim, S.; Song, M.S.; Kim, Y.M. Quantitative and qualitative changes in antibiotic resistance genes after passing through treatment processes in municipal wastewater treatment plants. Sci. Total Environ. 2017, 605-606, 906-914. [CrossRef]

26. Yoo, K.; Yoo, H.; Lee, J.M.; Shukla, S.K.; Park, J. Classification and Regression Tree Approach for Prediction of Potential Hazards of Urban Airborne Bacteria during Asian Dust Events. Sci. Rep. 2018, 8, 11823. [CrossRef]

27. Radosevich, J.L.; Wilson, W.J.; Shinn, J.H.; DeSanties, T.Z.; Andersen, G.L. Development of a high-volume aerosol collection system for the identification of air-borne micro-organisms. Lett. Appl. Microbiol. 2002, 34, 162-167. [CrossRef]

28. Bolger, A.M.; Lohse, M.; Usadel, B. Trimmomatic: A flexible trimmer for Illumina sequence data. Bioinformatics 2014, 30, 2114-2120. [CrossRef] [PubMed]

29. Yin, X.L.; Jiang, X.T.; Chai, B.L.; Li, L.G.; Yang, Y.; Cole, J.R.; Tiedje, J.M.; Zhang, T. ARGs-OAP v2.0 with an expanded SARG database and Hidden Markov Models for enhancement characterization and quantification of antibiotic resistance genes in environmental metagenomes. Bioinformatics 2018, 34, 2263-2270. [CrossRef] 
30. Kristiansson, E.; Fick, J.; Janzon, A.; Grabic, R.; Rutgersson, C.; Weijdegard, B.; Soderstrom, H.; Larsson, D.G.J. Pyrosequencing of antibiotic-contaminated river sediments reveals high levels of resistance and gene transfer elements. PLoS ONE 2011, 6, e17038. [CrossRef]

31. Fang, H.; Huang, K.; Yu, J.; Ding, C.; Wang, Z.; Zhao, C.; Yuan, H.; Wang, Z.; Wang, S.; Hu, J.; et al. Metagenomic analysis of bacterial communities and antibiotic resistance genes in the Eriocheir sinensis freshwater aquaculture environment. Chemosphere 2019, 224, 202-211. [CrossRef]

32. Truong, D.T.; Franzosa, E.A.; Tickle, T.L.; Scholz, M.; Weingart, G.; Pasolli, E.; Tett, A.; Huttenhower, C.; Segata, N. MetaPhlAn2 for enhanced metagenomic taxonomic profiling. Nat. Methods 2015, 12, 902-903. [CrossRef]

33. Brown, K.D.; Kulis, J.; Thomson, B.; Chapman, T.H.; Mawhinney, D.B. Occurrence of antibiotics in hospital, residential, and dairy effluent, municipal wastewater, and the Rio Grande in New Mexico. Sci. Total Environ. 2006, 366, 772-783. [CrossRef] [PubMed]

34. Choi, K.; Kim, Y.; Park, J.; Park, C.K.; Kim, M.; Kim, H.S.; Kim, P. Seasonal variations of several pharmaceutical residues in surface water and sewage treatment plants of Han River, Korea. Sci. Total Environ. 2008, 405, 120-128. [CrossRef] [PubMed]

35. Ok, Y.S.; Kim, S.C.; Kim, K.R.; Lee, S.S.; Moon, D.H.; Lim, K.J.; Sung, J.-K.; Hur, S.-O.; Yang, J.E. Monitoring of selected veterinary antibiotics in environmental compartments near a composting facility in Gangwon Province, Korea. Environ. Monit. Assess. 2011, 174, 693-701. [CrossRef] [PubMed]

36. Park, J.; Han, E.; Lee, S.O.; Kim, D.S. Antibiotic use in South Korea from 2007 to 2014: A health insurance database-generated time series analysis. PLoS ONE 2017, 12, e0177435. [CrossRef] [PubMed]

37. Zhang, T.; Yang, Y.; Pruden, A. Effect of temperature on removal of antibiotic resistance genes by anaerobic digestion of activated sludge revealed by metagenomic approach. Appl. Microbiol. Biotechnol. 2015, 99, 7771-7779. [CrossRef] [PubMed]

38. Gao, P.; Munir, M.; Xagoraraki, I. Correlation of tetracycline and sulfonamide antibiotics with corresponding resistance genes and resistant bacteria in a conventional municipal wastewater treatment plant. Sci. Total Environ. 2012, 421-422, 173-183. [CrossRef]

39. Toth, M.; Antunes, N.T.; Stewart, N.K.; Frase, H.; Bhattacharya, M.; Smith, C.A.; Vakulenko, S.B. Class D $\beta$-lactamases do exist in Gram-positive bacteria. Nat. Chem. Biol. 2015, 12, 9. [CrossRef]

40. Bonomo, R.A. $\beta$-Lactamases: A Focus on Current Challenges. Cold Spring Harb. Perspect Med. 2017, 7, a025239. [CrossRef]

41. Wang, Z.; Zhang, X.; Huang, K.; Miao, Y.; Shi, P.; Liu, B.; Long, C.; Li, A. Metagenomic Profiling of Antibiotic Resistance Genes and Mobile Genetic Elements in a Tannery Wastewater Treatment Plant. PLoS ONE 2013, 8, e76079. [CrossRef] [PubMed]

42. Munir, M.; Wong, K.; Xagoraraki, I. Release of antibiotic resistant bacteria and genes in the effluent and biosolids of five wastewater utilities in Michigan. Water Res. 2011, 45, 681-693. [CrossRef] [PubMed]

43. Lindsey, M.E.; Meyer, T.M.; Thurman, E.M. Analysis of trace levels of sulfonamide and tetracycline antimicrobials in groundwater and surface water using solid-phase extraction and liquid chromatography/mass spectrometry. Anal. Chem. 2001, 73, 4640-4646. [CrossRef] [PubMed]

44. Batt, A.L.; Bruce, I.B.; Aga, D.S. Evaluating the vulnerability of surface waters to antibiotic contamination from varying wastewater treatment plant discharges. Environ. Pollut. 2006, 142, 295-302. [CrossRef]

45. Antunes, P.; Machado, J.; Sousa, J.C.; Peixe, L. Dissemination of sulfonamide resistance genes (sul1, sul2, and sul3) in Portuguese Salmonella enterica strains and relation with integrons. Antimicrob. Agents Chemother. 2005, 49, 836-839. [CrossRef] [PubMed]

46. Ma, Y.; Wilson, C.A.; Novak, J.T.; Riffat, R.; Aynur, S.; Murthy, S.; Pruden, A. Effect of various sludge digestion conditions on sulfonamide, macrolide, and tetracycline resistance genes and class I integrons. Environ. Sci. Technol. 2011, 45, 7855-7861. [CrossRef] [PubMed]

47. Xie, J.E.; Jin, L.; Luo, X.; Zhao, Z.; Li, X. Seasonal disparities in airborne bacteria and associated antibiotic resistance Genes in PM2.5 between Urban and Rural Sites. Environ. Sci. Technol. Lett. 2018, 5, 74-79. [CrossRef]

48. Sapkota, A.R.; Ojo, K.K.; Roberts, M.C.; Schwab, K.J. Antibiotic resistance genes in multidrug-resistant Enterococcus spp. and Streptococcus spp. recovered from the indoor air of a large-scale swine-feeding operation. Lett. Appl. Microbiol. 2006, 43, 534-540. [CrossRef] 
49. McEachran, A.D.; Blackwell, B.R.; Delton Hanson, J.; Wooten, K.J.; Mayer, G.D.; Cox, S.B.; Smith, P.N. Antibiotics, Bacteria, and Antibiotic Resistance Genes: Aerial Transport from Cattle Feed Yards via Particulate Matter. Environ. Heal. Persp. 2015, 123, 337-343. [CrossRef]

50. Gandolfi, I.; Franzetti, A.; Bertolini, V.; Gaspari, E.; Bestetti, G. Antibiotic resistance in bacteria associated with coarse atmospheric particulate matter in an urban area. J. Appl. Microbiol. 2011, 110, 1612-1620. [CrossRef]

51. Novo, A.; André, S.; Viana, P.; Nunes, O.C.; Manaia, C.M. Antibiotic resistance, antimicrobial residues and bacterial community composition in urban wastewater. Water Res. 2013, 47, 1875-1887. [CrossRef]

52. Wu, D.; Huang, Z.; Yang, K.; Graham, D.; Xie, B. Relationships between antibiotics and antibiotic resistance gene levels in municipal solid waste leachates in Shanghai, China. Environ. Sci. Technol. 2015, 49, 4122-4128. [CrossRef]

53. Penton, C.R.; Gupta, V.V.S.R.; Yu, J.; Tiedje, J.M. Size matters: Assessing optimum soil sample size for fungal and bacterial community structure analyses using high throughput sequencing of rRNA gene amplicons. Front. Microbiol. 2016, 7, 824. [CrossRef] [PubMed]

54. Fahrenfeld, N.L.; Reyes, H.D.; Eramo, A.; Akob, D.M.; Mumford, A.C.; Cozzarelli, I.M. Shifts in microbial community structure and function in surface waters impacted by unconventional oil and gas wastewater revealed by metagenomics. Sci. Total Environ. 2017, 580, 1205-1231. [CrossRef] [PubMed]

55. Wagner, M.; Loy, A. Bacterial community composition and function in sewage treatment systems. Curr. Opin. Biotechnol. 2002, 13, 218-227. [CrossRef]

56. Zhang, T.; Shao, M.F.; Ye, L. 454-Pyrosequencing reveals bacterial diversity of activated sludge from 14 sewage treatment plants. ISME J. 2012, 6, 1137-1147. [CrossRef] [PubMed]

57. Han, Y.; Wang, Y.; Li, L.; Xu, G.; Liu, J.; Yang, K. Bacterial population and chemicals in bioaerosols from indoor environment: Sludge dewatering houses in nine municipal wastewater treatment plants. Sci. Total Environ. 2018, 618, 469-478. [CrossRef] [PubMed]

58. Gillings, M.R.; Gaze, W.H.; Pruden, A.; Smalla, K.; Tiedje, J.M.; Zhu, T. Using the class 1 integron-integrase gene as a proxy for anthropogenic pollution. ISME J. 2015, 9, 1269-1279. [CrossRef] [PubMed]

59. Zhang, T.; Zhang, X.X.; Ye, L. Plasmid metagenome reveals high levels of antibiotic resistance genes and mobile genetic elements in activated sludge. PLoS ONE 2011, 6, e26041. [CrossRef] [PubMed]

60. De Souza, M.L.; Wackett, L.P.; Sadowsky, M.J. The atzABC genes encoding atrazine catabolism are located on a self-transmissible plasmid in Pseudomonas sp. strain ADP. Appl. Environ. Microbiol. 1998, 64, 2323-2326. [CrossRef] [PubMed]

61. Lang, K.S.; Danzeisen, J.L.; Xu, W.; Johnson, T.J. Transcriptome mapping of pAR060302, a bla CMY-2-positive broad-host-range IncA/C plasmid. Appl. Environ. Microbiol. 2012, 78, 3379-3386. [CrossRef]

62. Kieffer, N.; Nordmann, P.; Millemann, Y.; Poirel, L. Functional characterization of a Miniature Inverted Transposable Element at the origin of mcr-5 gene acquisition in Escherichia coli. Antimicrob. Agents Chemother. 2017, 63, e00559-19. [CrossRef]

63. Ju, F.; Li, B.; Ma, L.; Wang, Y.; Huang, D.; Zhang, T. Antibiotic resistance genes and human bacterial pathogens: Co-occurrence, removal, and enrichment in municipal sewage sludge digesters. Water Res. 2016, 91, 1-10. [CrossRef] [PubMed]

64. Jia, S.; Shi, P.; Hu, Q.; Li, B.; Zhang, T.; Zhang, X.X. Bacterial community shift drives antibiotic resistance promotion during drinking water chlorination. Environ. Sci. Technol. 2015, 49, 12271-12279. [CrossRef] [PubMed]

65. Su, J.Q.; Wei, B.; Ou-Yang, W.; Huang, F.; Zhao, Y.; Xu, H.; Zhu, Y. Antibiotic resistome and its association with bacterial communities during sewage sludge composting. Environ. Sci. Technol. 2015, 49, 7356-7363. [CrossRef] [PubMed]

(C) 2020 by the authors. Licensee MDPI, Basel, Switzerland. This article is an open access article distributed under the terms and conditions of the Creative Commons Attribution (CC BY) license (http://creativecommons.org/licenses/by/4.0/). 